KS. KAZIMIERZ DULLAK

Wydział Teologiczny Uniwersytetu Szczecińskiego

\title{
PRAESUMPTIO W KODEKSIE JANA PAWŁA II Z 1983 ROKU
}

Treść: Wprowadzenie. - 1. Presumpcja w ogólności. - 1.1. Presumpcja faktyczna. - 1.2. Presumpcja prawna. - 2. Presumpcja w szczególności. - 2.1. Presumpcja prawna dotycząca osób. - 2.2. Presumpcja prawna dotycząca okoliczności. - 2.3. Presumpcja prawna dotycząca rzeczy. - Zakończenie.

\section{Wprowadzenie}

W mowie potocznej języka polskiego używa się rozmaitych synonimów na określenie łac. praesumptio czyli domniemanie ${ }^{1}$. Taki stan rzeczy wynika z tego, że domniemanie dotyczy różnych dziedzin życia. Zawężając nasz obszar zainteresowania do nauk prawnych, praesumptio pozostaje sformułowaniem interdyscyplinarnym, a $\mathrm{z}$ tego wynika fakt, iż nie jest jednoznaczne. Stąd warto przypatrzeć się rodzajom domniemań, a następnie kontekstom ich występowania na gruncie kodeksowego prawa obowiązującego w Kościele łacińskim. Wcześniej jednak wydaje się być wskazanym, przedstawienie w niniejszym przedłożeniu, wyjaśnienia natury ogólnej.

\footnotetext{
${ }^{1}$ M.in.: abstrakcja, domysł, hipoteza, idea, koncepcja, pogląd, przypuszczenie, sąd, spekulacja, teoria, teza, koniektura, podejrzenie, presumpcja, przeczucie, przewidywanie, supozycja, założenie, sugestia, antycypacja, przekonanie, przeświadczenie, przesłanka, głos wewnętrzny, intuicja, hipotetycznie, potencjalnie, domyślnie, telepatia, możliwie, rzekomo, zob.: http://synonim.net/synonim/domniemanie [Dostęp 29.05.2016].
} 


\section{Presumpcja w ogólności}

Domniemanie w Kodeksie z 1917 r. $^{2}$ zostało sformułowane jako prawdopodobne przypuszczenie o prawdziwości rzeczy niepewnej, czyli rei incertae probabilis coniectura ${ }^{3}$. F. Bączkowicz rozróżnia w prawie kościelnym domniemanie prawne - które stanowi sama ustawa oraz sędziowskie - które sędzia sam dowodzi ${ }^{4}$, zwane również domniemaniem faktycznym.

Kanony mówiące o domniemaniach w Kodeksie Jana Pawła II zostały przez prawodawcę zamieszczone w tytule o dowodach siódmej księgi, traktującej o procesach. Takie uplasowanie można tłumaczyć według R. Sztychmilera tym, że prawodawca uważa je za środki dowodowe ${ }^{5}$. Niektórzy jednak podważają dowodowy charakter domniemań. W obowiązującym kodeksie istnieje podział domniemań na prawne i sędziowskie (czyli identycznie jak w poprzednim kodeksie). Definicję domniemania podaje kanon 1584 obowiązującego kodeksu: jest to uzasadnione wnioskowanie, a nie zwykłe przypuszczenie autentyczności jakiegoś faktu na podstawie innych faktów, albo okoliczności już udowodnionych. Jeżeli prawodawca przyjął domniemanie, nazywa się je prawnym, a jeżeli przyjmuje je sędzia, nazywane jest sędziowskim lub faktycznym.

Presumpcja w KPK ma częste zastosowanie w sprawach o nieważność małżeństwa oraz w sprawach karnych. Źródłem domniemań w sprawach karnych są poszlaki, czyli różne okoliczności, które wpływają na niekorzyść oskarżonego. Poszlaki jednak nie są dowodem wprost na uznanie kogoś winnym ${ }^{6}$.

\footnotetext{
${ }^{2}$ Benedy t XV, Codex Iuris Canonici Pii X Pontificis Maximi iussu digestus Benedicti Papae XV auctoritate promulgatus, Vaticanis 1933.

${ }^{3}$ Por. M. FĄKA, Normy ogólne kanonicznego procesu sądowego, cz. 2, Warszawa 1978, s. 211.

${ }^{4}$ Por. F. BĄczkowicz, Prawo..., dz. cyt., s. 116-117.

${ }^{5}$ Por. J. Krukowski (red.), Komentarz do kodeksu prawa kanonicznego, t. 5, Poznań 2007, s. 239.

${ }^{6}$ Por. T. Pawluk, Prawo kanoniczne według kodeksu Jana Pawła II, t. 4, Olsztyn 1990, s. 282.
} 
W sprawie o nieważność małżeństwa presumpcja dotyczy zwłaszcza wad zgody małżeńskiej. Sędzia może wytoczyć domniemanie biorąc za podstawę okoliczności, które poprzedziły zawarcie małżeństwa, były obecne podczas jego zawierania oraz ujawniły się po ślubie ${ }^{7}$. Jednak, aby sędzia mógł orzec o nieważności małżeństwa, musi mieć pewność moralną. Pewność moralna nie może się ograniczać jedynie do dowodów i domniemań, lecz powinna zostać wykluczona wszelka pozytywna możliwość błędu ${ }^{8}$.

Należy już w tym miejscu wspomnieć, że wszystkie domniemania prawne występujące w aktualnie obowiązującym kodeksie są zwykłe czyli wzruszalne, to oznacza że można je obalić przeciwdowodem. Jeżeli chodzi o domniemania faktyczne, to w KPK/83 one nie występują. Owe domniemania wnioskuje dopiero sam sędzia podczas procesu. Wynikają one $\mathrm{z}$ logicznego rozumowania sędziego na podstawie dowodów lub zeznań świadków.

\subsection{Presumpcja faktyczna}

O domniemaniu faktycznym mówi się wtedy, gdy jest wnioskowane przez samego sędziego, dlatego takie domniemanie nosi nazwę domniemania sędziowskiego (praesumptio hominis), jest ono wyprowadzane $z$ autentycznych przesłanek. Stwarza to możliwość dotarcia do prawdy obiektywnej. Możność będzie większa, im więcej zgodnych wniosków sędzia wytoczy z różnych przesłanek ${ }^{9}$. Ważne jest to, aby owe domniemanie nie opierało się na zwykłych domysłach teoretycznych, pozbawionych podstaw faktycznych. Konieczna jest prawdziwość tych domysłów, to znaczy że musiały się one rzeczywiście wydarzyć. Sędzia powinien posłużyć się presumpcją z faktów

\footnotetext{
${ }^{7}$ Por. tamże, s. 282.

${ }^{8}$ Por. W. Wenz, P. WróBlewski, Urząd obrońcy węzła i procesowe decyzje sędziego na etapie wyrokowania. Zagadnienia wybrane z procesu o nieważność małżeństwa, Wrocław 2007, s. 151-152.

${ }^{9}$ Por. tamże, s. 281.
} 
pewnych i ścisłych mających związek z głównym faktem, o który toczy się spór ${ }^{10}$.

Fakt, na którym ma się oprzeć domniemanie sędziowskie musi posiadać trzy podstawowe przymioty:

1/ być pewny, czyli prawdziwy (gdy fakt, który ma być udowodniony nie jest pewny, wówczas powinien być udowodniony; $\mathrm{z}$ faktów niepewnych nie należy wyciągać wniosków);

2/ konkretnie określony (nie można domniemywać np. że mąż kocha swoją żonę, ale trzeba określić czy ten konkretny mąż kocha swoją żonę - nie można stosować ekstrapolacji, bo może w omawianym przypadku nastąpić jakiś wyjątek);

3/ oraz pozostawać w ścisłym związku $\mathrm{z}$ faktem będącym przedmiotem sporu (przypuszczenia muszą opierać się bezpośrednio na fakcie spornym, tzn. nie można przypuszczenia budować na drugim przypuszczeniu) ${ }^{11}$.

Warto postawić pytanie: jaka jest rola domniemań sędziowskich? Przede wszystkim pełnią one rolę pomocniczą w stosunku do innych środków dowodowych. Można też stwierdzić, że wzmacniają argumenty jakich te środki dostarczają. Znaczenie takich presumpcji może być różne. Zależy to od liczby przesłanek oraz od ich prawdziwości, lecz nie można zapomnieć o bliższym lub dalszym związku przyczynowym faktów, na których te domniemania się opierają. Nie można jednak domniemań sędziowskich pozbawić ważnej roli dowodowej. Mogą się przyczynić do wyrobienia przez sędziego moralnej pewności, gdy tylko wnioski korelują ze sobą i są pewne oraz dają pełny obraz rzeczywistości ${ }^{12}$. Presumpcja sędziowska może być obalona. Gdyby się okazało, że jest ona nieprawdziwa, wówczas należy takie domniemanie znieść i utorować miejsce prawdzie.

\footnotetext{
${ }^{10}$ Por. tamże, s. 281-282.

${ }^{11}$ Por. M. FąKa, Normy ogólne..., dz. cyt., s. 213-214.

${ }^{12}$ Por. T. Pawluk, Prawo kanoniczne..., t. 4, dz. cyt., s. 282.
} 


\subsection{Presumpcja prawna}

Presumpcja prawna polega na przyjęciu na podstawie przepisu prawnego, niektórych faktów za udowodnione w przypadku braku dowodów przeciwnych ${ }^{13}$. Przykładem może posłużyć domniemanie dopełnienia małżeństwa, jeśli po zawarciu związku małżeńskiego, małżonkowie wspólnie zamieszkali ${ }^{14}$. Warto wspomnieć, że w procesach małżeńskich za ważnością związku raz zawartego przemawia zwykła presumpcja prawna ${ }^{15}$. Dzieli się ona na domniemanie prawne zwykłe (względne) i bezwzględne ${ }^{16}$. Domniemanie względne, jak sama nazwa wskazuje można obalić, gdy wykaże się nieautentyczność wniosku. Natomiast domniemanie bezwzględne występuje wtedy, gdy prawodawca nie dopuszcza wprost dowodu przeciwnego, ale dowód pośredni. Dowód ten musi wykazać nieautentyczność przesłanki, z której wniosek wynika ${ }^{17}$.

Jeżeli ktoś ma za sobą presumpcję prawną, wówczas jest zwolniony od obowiązku udowodnienia swoich twierdzeń. Obowiązek ten przechodzi na stronę przeciwną ${ }^{18}$. To oznacza, że strona, na której korzyść przemawia domniemanie, nie musi udowadniać swoich twierdzeń. W takim wypadku obowiązek wskazania fałszywego domniemania przechodzi na stronę przeciwną. Wówczas presumpcja musi ustąpić miejsca prawdzie, ponieważ obowiązuje zasada: praesumptio cedit veritat $^{19}$. Jednak nie tylko strona przeciwna może obalić domniemanie prawne, ale również sędzia $z$ racji swojego urzędu. Sędzia może podać swoje domniemanie jedynie na podstawie faktu pewnego i określonego, pozostającego w bezpośrednim związku z faktem, którego dotyczy dany spór.

\footnotetext{
${ }^{13}$ Por. M. Sitarz, Słownik prawa kanonicznego, Warszawa 2004, s. 43.

${ }^{14}$ Zob. kan. $1061 \$ 2$ KPK.

${ }^{15}$ Por. E. Sztafrowski, Prawo kanoniczne w okresie odnowy soborowej, t. 2, Warszawa 1979, s. 511.

${ }^{16}$ Por. M. Sitarz, Słownik..., dz. cyt., s. 43.

${ }^{17}$ Por. tamże, s. 43.

${ }^{18}$ Por. kan. 1585 KPK.

${ }^{19}$ Por. T. Pawluk, Prawo kanoniczne..., t. 4, dz. cyt., s. 281.
} 


\section{Presumpcja prawna w szczególności}

Kodeks Jana Pawła II posługuje się presumpcją prawną w odniesieniu do osób, okoliczności oraz rzeczy. Poniżej przyjrzyjmy się konstrukcjom prawnym w których te domniemania zostały zastosowane.

\subsection{Presumpcja dotycząca osób}

Pierwszym, $\mathrm{z}$ interesujących nas jest domniemanie zawarte w kan. 97. Prawo kanoniczne rozróżnia trzy kategorie osób fizycznych: pełnoletni, małoletni i dzieci. Pełnoletniość osiąga się po ukończeniu 18 lat, a małoletniość po ukończeniu 7 lat. Dziecko do siódmego roku życia jest małoletnie i uważane jest za nie posiadające używania rozumu. W tym wypadku nie jest to stricte presumpcja prawna, ale dyspozycja prawna, która pociąga za sobą niezdolność dziecka do jakichkolwiek działań prawnych w Kościele. Dziecko jest wolne od obowiązków ${ }^{20}$. U małoletniego, który skończył siódmy rok życia, domniemywa się używanie rozumu. Dopiero tutaj jest domniemanie prawne zwykłe, czyli wzruszalne. Może ono zostać obalone wprost lub pośrednio. Osoba taka może w pełni korzystać z uprawnień jej przysługujących, podlega władzy rodziców lub opiekunów prawnych, z wyjątkiem tych sytuacji, w których osoby małoletnie na podstawie prawa Bożego lub kanonicznego są wyjęte spod ich władzy (kan. $98 \$ 2)^{21}$.

Kolejne domniemanie prawne dotyczące osób traktuje o delegowaniu władzy wielu osobom (kan. $140 \$ 3$ ). Władza może być delegowana jednej tylko osobie bądź kilku osobom. Kilka osób może wykonywać władzę pojedynczo lub kolegialnie. Natomiast poszczególne osoby mogą być delegowane solidarnie, kolegialnie lub sukcesywnie ${ }^{22}$. Solidarnie, znaczy że każdy z nich z osobna niezależnie od drugiego jest kompetentny do załatwienia tej samej sprawy. Przykładem jest tutaj delegacja dana przez proboszcza dwóm duchownym do asystowania

\footnotetext{
${ }^{20}$ Por. J. Krukowski (red.), Komentarz do kodeksu prawa kanonicznego, t. 1, Poznań 2003, s. 167.

${ }^{21}$ Por. E. Sztafrowski, Podręcznik prawa kanonicznego, t. 1, Warszawa 1985, s. 218.

${ }^{22}$ Por. J. Krukowski (red.), Komentarz do..., t. 1, dz. cyt., s. 227.
} 
przy jednym i tym samym zawieraniu małżeństwa. Wtedy każdy $\mathrm{z}$ nich, jeden niezależnie od drugiego, może ważnie asystować przy konkretnym ślubowaniu. Kolegialnie, znaczy nie indywidualnie. Ważny akt mogą dokonać wówczas, gdy postępują według zasad działania kolegialnego. Natomiast sukcesywnie znaczy z wyraźnym zastrzeżeniem, że drugi podejmuje sprawę, gdy pierwszy swą funkcję skończy. Przykładem jest tutaj decyzja biskupa o wskazaniu kilku swoich następców, którzy kolejno by go zastępowali, gdyby sytuacja się tego domagała ${ }^{23}$. Domniemywa się, że władza delegowana kilku osobom została im delegowana solidarnie ${ }^{24}$. Domniemywa się, że została delegowana każdemu $\mathrm{z}$ osobna ${ }^{25}$. Jest to presumpcja prawna zwykła, którą można obalić dowodem przeciwnym.

Kan. $283 \$ 1$ zawiera również domniemanie prawne dotyczące osób. Traktuje on o obowiązku rezydencji. Chodzi o to, że duchowni nie powinni oddalać się poza diecezję na dłuższy czas, bez zgody własnego ordynariusza. Prawo jednak nie określa co oznacza sformułowanie „dłuższy czas”. Reguła ta jest zaczerpnięta z poprzedniego kodeksu. Ówcześni komentatorzy byli zdania, że chodzi o okres od jednego miesiąca do sześciu miesięcy. Inni natomiast, że chodzi dokładnie o trzy miesiące. Jednak najlepszą odpowiedzią jest taki czas, który by nie przeszkodził w wypełnieniu obowiązków służbowych. Zależy to od tego, czy kapłan jest związany z miejscem rezydencjalnie, tzn. duszpastersko, czy nierezydencjalnie oraz od okoliczności miejsca i czasu ${ }^{26}$. Zakazany czas nieobecności we własnej diecezji powinien być określony w prawie partykularnym ${ }^{27}$. Przykładem może posłużyć regulacja I Synodu Toruńskiego, który dookreśla, że kapłan pracujący w diecezji ma prawo do miesięcznego urlopu wypoczynkowego.

\footnotetext{
${ }^{23}$ Por. M. Żurowski, Problem władzy i powierzania urzędów w Kościele katolickim, Kraków 1984, s. 148.

${ }^{24}$ Zob. J. Krukowski (red.), Komentarz do..., t. 1, dz. cyt., s. 227.

${ }^{25}$ Por. E. Sztafrowski, Podręcznik..., t. 1, dz. cyt., s. 248.

${ }^{26}$ Por. J. Krukowski (red.), Komentarz do kodeksu prawa kanonicznego, t. 2/1, Poznań 2005, s. 106-107.

${ }^{27}$ Zob. T. PAwluk, Prawo kanoniczne według kodeksu Jana Pawła II, t. 2, Olsztyn 1986, s. 96.
} 
Wszelkie szczegóły związane z dniami wolnymi, m.in. dotyczącymi tygodniowego trybu pracy doprecyzowuje Instrukcja o urlopach $i$ wyjazdach pozaurlopowych kapłanów ${ }^{28}$. Każda nieobecność powinna być zabezpieczona niezbędną posługą duszpasterską wiernych. Urząd rezydencjalny obowiązuje proboszcza parafii. Natomiast urząd nie jest rezydencjalny, gdy dotyczy na przykład wykładowców seminarium. Ci kapłani, aby wypełniać swoją funkcję, nie muszą koniecznie przebywać na określonym miejscu ${ }^{29}$. Gdy chodzi o pełniących urząd rezydencjalny, zabronione jest nie tylko opuszczanie na dłużej swojej diecezji, lecz także nie uzasadnione opuszczanie miejsca pełnienia urzędu. Obowiązek przebywania w diecezji nie ma charakteru bezwzględnego, gdyż można ją opuszczać za zezwoleniem ordynariusza. Wystarczy tutaj zezwolenie domniemane (licentia praesumpta). Może ono mieścić się na przykład w zezwoleniu ordynariusza na wykonanie obowiązków poza diecezją ${ }^{30}$. Jest to domniemanie prawne zwykłe, które można obalić przeciwdowodem.

Każdy biskup może używać pontyfikaliów na terenie swojej diecezji. Jednak poza nią musi mieć zgodę ordynariusza miejsca. Właśnie tego dotyczy kolejna presumpcja prawna. Kan. 390 jest normą uprawniającą biskupa diecezjalnego do używania pontyfikaliów, czyli insygniów biskupich - mitry i pastorału, na terenie swojej diecezji. Jednak poza diecezją tylko za wyraźną lub domniemaną zgodą tamtejszego ordynariusza miejsca. Użycie pontyfikaliów jest manifestacją wysokiej pozycji biskupa w Kościele partykularnym ${ }^{31}$. Presumpcja ta może zostać obalona.

Kanon 764 jest kolejnym miejscem, w którym występuje presumpcja prawna. Nie zostało tu użyte słowo „domniemanie”, ale słowo „domyślną”. Dotyczy kwestii przepowiadania słowa Bożego. Na pierwszym miejscu upoważnieni do głoszenia słowa Bożego są biskupi. Mogą oni to czynić wszędzie, nawet w kościołach i instytutach

\footnotetext{
${ }^{28}$ Prawo partykularne Kościoła Toruńskiego, Toruń 2011, s. 36; 284-285.

${ }^{29}$ Por. T. Pawluk, Prawo kanoniczne..., t. 2, dz. cyt., s. 145.

${ }^{30}$ Por. tamże, s. 146.

${ }^{31}$ Por. J. Krukowski (red.), Komentarz do..., t. 2/1, dz. cyt., s. 250.
} 
zakonnych na prawie papieskim, chyba że biskup diecezjalny zarządził coś innego ${ }^{32}$. Upoważnienie do głoszenia słowa Bożego również wszędzie, ale za domniemaną zgodą rządcy kościoła, przysługuje kapłanom i diakonom. Wyjątkiem są sytuacje, przez które dane upoważnienie zostało ograniczone lub uchylone przez ordynariusza, albo prawo partykularne wymaga wyraźnego zezwolenia. Ważne jest to, że upoważnienie to nie zezwala na głoszenie słowa w kościołach zakonnych lub oratoriach. Kapłan i diakon musi najpierw uzyskać zgodę przynajmniej domniemaną, rządcy kościoła, w którym ma być to słowo głoszone ${ }^{33}$. Domniemanie to można obalić, podobnie jak poprzednie, dowodem przeciwnym.

Podobną presumpcję znaleźć można w kan. $886 \$ 2$. Chodzi dokładnie o godziwe udzielanie bierzmowania w obcej diecezji. Biskup poza swoją diecezją może bierzmować tylko swoich podwładnych, chyba że uzyskał zezwolenie miejscowego biskupa diecezjalnego ${ }^{34}$. Biskup tytularny chociaż jest szafarzem zwyczajnym bierzmowania, jeśli nie kieruje Kościołem partykularnym, może godziwie bierzmować tylko wtedy, gdy ma zezwolenie właściwego biskupa diecezjalnego ${ }^{35}$. W swojej diecezji biskup może prawnie udzielać sakramentu bierzmowania także obcym, chyba że zabrania tego wyraźny zakaz ich własnego ordynariusza ${ }^{36}$. Jeśli biskup diecezjalny bierzmuje własnych wiernych, poza własnym terytorium, nie potrzebuje niczyjego zezwolenia, z ograniczeniem związanym $\mathrm{z}$ użyciem stroju pontyfikalnego. Należy bowiem zastosować unormowanie wynikające z kan. 390,

\footnotetext{
${ }^{32}$ Zob. kan. 763 KPK.

${ }^{33}$ Por. W. GóRAlski, Posługa słowa Bożego według Kodeksu Prawa Kanonicznego z 1983 r., Częstochowskie Studia Teologiczne 12-13 (1985), s. 435-436.

${ }^{34}$ Por. K. MikoŁajczuk, Sakrament bierzmowania (chryzmacji) w prawie kodeksowym Kościoła katolickiego, w: Historia et Ius. Książka pamiątkowa ku czci Księdza Profesora Henryka Karbownika, A. Dębiński, G. Górski (red.), Lublin 1998, s. 382.

${ }^{35}$ Zob. P. Hemperek, W. Góralski, F. Przytula, J. Bakalarz, Komentarz do prawa kanonicznego, t. 3, Lublin 1986, s. 102.

${ }^{36}$ Zob. E. SzTafrowski, Podręcznik prawa kanonicznego, t. 3, Warszawa 1986, s. 162.
} 
o którym wyżej ${ }^{37}$. Jeśli biskup ma zamiar bierzmować poza własną diecezją obcych podwładnych, zawsze potrzebuje zgody ordynariusza danego miejsca. Zgodę taką musi uzyskać nawet wówczas, jeśli nie planuje użycia stroju pontyfikalnego. Biskup może domniemywać, że miejscowy ordynariusz zgadza się na bierzmowanie w jego diecezji także miejscowych wiernych. Nie można natomiast domniemywać istnienia takiej zgody wówczas, gdy wiadomo, że ordynariusz miejscowy wydał swoim wiernym zakaz przyjęcia sakramentu bierzmowania od kogo innego poza nim samym. W takich okolicznościach trzeba by się zwracać o specjalne zezwolenia na bierzmowanie ${ }^{38}$.

Następne domniemanie, z omawianej grupy, występuje w kan. $969 \$ 1$. Kanon ten traktuje o upoważnieniu do spowiadania udzielonym przez ordynariusza miejsca. Ordynariusz, który nie musi być biskupem, udzielają uprawnienia do spowiadania prezbiterom. Nie mówi się w przypadku tego kanonu o kapłanach czyli prezbiterach i biskupach, ale jedynie o prezbiterach. Skoro biskupi mają uprawnienie do spowiadania $\mathrm{z}$ mocy samego prawa, ordynariusz miejsca może udzielać tego uprawnienia samym prezbiterom ${ }^{39}$. Prezbiterzy będący członkami instytutów zakonnych nie powinni z niego korzystać bez zezwolenia przynajmniej domniemanego własnego przełożonego ${ }^{40}$. Potrzebne jest tutaj pozwolenie przełożonych ${ }^{41}$. Wymagane jest ono tylko do godziwości ${ }^{42}$. Chodzi o to, że zakonnicy mają pewne zobowiązania wobec swego przełożonego i wspólnoty, w której prze-

\footnotetext{
${ }^{37}$ Zob. M. PAstuszko, Szafarz sakramentu bierzmowania, Prawo Kanoniczne 1-2 (1990), s. 126.

${ }^{38}$ Zob. M. PAstuszko, Uprawnienia i obowiazki biskupa oraz prezbitera co do udzielania sakramentu bierzmowania (kan. 882-888), Kieleckie Studia Teologiczne 3 (2004), s. 439.

${ }^{39}$ Zob. M. PAstuszko, Uprawnienie do sprawowania sakramentu pokuty (kan. 966-975), Prawo Kanoniczne 3-4 (1994), s. 215.

${ }^{40}$ Zob. Z. JANCZEwski, Facultas ad confessiones jako akt powierzenia kapłanowi misji sprawowania sakramentu pokuty i pojednania w Kościele katolickim, Annales Canonici 3 (2007), s. 110.

${ }^{41}$ Por. P. Hemperek, W. Góralski, F. Przytula, J. Bakalarz, Komentarz..., t. 3, dz. cyt., s. 159.

${ }^{42}$ Por. E. Sztafrowski, Podręcznik..., t. 3, dz. cyt., s. 249.
} 
bywają. Nie może być jednak tak, żeby zakonnik mieszkał w domu zakonnym, a robił, co sam chce lub przyjmował zlecenia pracy od kogoś z zewnątrz, chociażby byłby to ordynariusz miejsca ${ }^{43}$. Presumpcja zawarta w tym kanonie może zostać przeważone dowodem przeciwnym.

Kolejny kanon dotyczy szafarza sakramentu namaszczenia chorych. Domniemanie prawne zawarte jest w kan. $1003 \$ 2$. Autor obowiązującego kodeku nie wymienia literalnie nikogo z uprawnionych do namaszczenia chorych. Zamiast tego w $\$ 2$ pojawia się wyrażenie obejmujące wszystkich duszpasterzy. Nawet proboszczowie nie zostali wyszczególnieni w tym kontekście. Wydaje się, że prawodawcy chodzi o to, by możliwie jak największa ilość kapłanów była uprawniona do sprawowania tegoż sakramentu ${ }^{44}$. Szafarzem uprawnionym do udzielania namaszczenia jest każdy kapłan, któremu zlecono duszpasterstwo określonej wspólnoty wiernych ${ }^{45}$. Zwyczajnie tę rolę spełniają kapłani, którym powierzono troskę o chorych i przebywających w szpitalach oraz przełożonych kleryckich wspólnot zakonnych. Gdy jest uzasadniona przyczyna wówczas tego sakramentu może udzielić jakikolwiek kapłan, za zgodą domniemaną kapłana odpowiedzialnego i uprawionego do udzielenia namaszczenia chorym. Natomiast gdyby była taka sytuacja, że udzielono namaszczenia w nagłym wypadku bez domniemanej zgody kapelana lub proboszcza, należy powiadomić o tym kapelana szpitala lub proboszcza ${ }^{46}$. Poza tym nie podkreśla się, by domniemanie zgody miejscowego duszpasterza było „rozumne” co nie oznacza by domniemana zgoda mogła być „nierozumna” ${ }^{47}$.

\footnotetext{
${ }^{43}$ Por. M. Pastuszko, Sakrament pokuty i pojednania, Kielce 1999, s. 229.

${ }^{44}$ Por. M. Pastuszko, Sakrament namaszczenia chorych $w$ Nowym Prawie Kanonicznym, w: J. Syryjczyk (red.), Duszpasterstwo w świetle Nowego Kodeksu Prawa Kanonicznego, Warszawa 1985, s. 174.

${ }^{45}$ Por. B. W. Zubert, Sakrament namaszczenia chorych - wykładnia obowiązujących przepisów kodeksowych, Rocznik Nauk Prawnych 5 (1995), s. 36.

${ }^{46}$ Por. P. Hemperek, W. Góralski, F. PrzytuŁa, J. Bakalarz, Komentarz..., t. 3, dz. cyt., s. 179-180.

${ }^{47}$ Por. M. Pastuszko, Sakrament namaszczenia chorych..., dz. cyt., s. 175-176.
} 
Kanon $1096 \$ 2$ należy do grupy przepisów mówiących o zgodzie małżeńskiej, a ściślej o wadach zgody małżeńskiej. Małżeństwo jest trwałym związkiem między mężczyzną a kobietą skierowanym do zrodzenia potomstwa przez jakieś seksualne współdziałanie. Nie wymaga się więc jakiejś szczegółowej wiedzy o małżeństwie, ale wystarczy znajomość elementów istotnych, potrzebnych do osiągnięcia celu praktycznego. Aktualnie, kiedy to uświadomienie jest powszechnie wprowadzane do programów nauczania, trudno przypuścić, aby w konkretnym wypadku kandydat do małżeństwa nie posiadł tej podstawowej wiedzy. Nieważnie zawierałby małżeństwo np. ten, kto uważa, że jest ono przejściowym związkiem przyjaźni czy pomocy. Prawodawca w $\$ 2$ omawianego kanonu stwierdza, że po osiągnięciu dojrzałości nie domniemywa się takiej ignorancji. Można stwierdzić, że presumpcja ta zakłada, iż po osiągnięciu dojrzałości taka ignorancja nie zachodzi. Jest to domniemanie dopuszczające argument przeciwny, polegający na rzeczywistym i faktycznym braku świadomości nupturienta. Brak ten należy wykazać prawnymi dowodami ${ }^{48}$. Prawodawca przyjmuje, że pewne uwarunkowania biograficzne mogą uniemożliwić albo zdeformować naturalne poznanie istoty małżeństwa przez nupturienta, ale ciężarem udowodnienia obarcza tego, kto jest już dojrzały, to jest mężczyznę albo kobietę, których ciało już dojrzało do prokreacji ${ }^{49}$. Na tę presumpcję powołuje się Rota Rzymska w wyrokach z kan. 1095 n. $2^{50}$.

Następne domniemanie, $\mathrm{z}$ omawianej grupy, dotyczy instytucji separacji. Chodzi o kanon $1152 \$ 2$. Choć małżeństwo między ochrzczonymi jest nierozerwalne, to jednak wymaganie dochowania wspólnoty życia nie jest absolutne i dopuszcza wyjątki usankcjonowane instytucją separacji podczas trwania węzła małżeńskiego. Separacja, albo

\footnotetext{
${ }^{48}$ Por. J. GręźLikowski, Czy w Kościele sa rozwody?, Włocławek 2001, s. 95.

${ }^{49}$ Por. P. J. VILADRICH, Konsens malżeński, sposoby prawnej oceny i interpretacji w kanonicznych procesach o stwierdzenie nieważności małżeństwa (kanony 1095-1107 Kodeksu Prawa Kanonicznego), Warszawa 2002, s. 174.

${ }^{50}$ Zob. D. Konieczny, Zagadnienie poważnego braku rozeznania oceniajacego co do istotnych praw i obowiązków matżeńskich wzajemnie przekazywanych i przyjmowanych (kan. 1095 nr 2), Studia Diecezji Radomskiej 4 (2002), s. 236.
} 
inaczej rozdzielenie, jest to zerwanie lub zaniechanie wspólnego pożycia małżonków mimo trwania ich węzła małżeńskiego i wynikającej zeń przeciwności. Rozdział ten może być dozgonny lub też czasowy, kończący się $\mathrm{z}$ upływem czasu lub w razie ustania jego przyczyn ${ }^{51}$. Prawodawca zaleca, aby współmałżonek pobudzony chrześcijańską miłością i troską o dobro rodziny, nie odmawiał stronie winnej przebaczenia oraz nie zrywał z nią życia małżeńskiego. Jednak gdy wyraźnie lub milcząco nie darował winy, ma prawo przerwać pożycie małżeńskie, chyba że zgodził się na cudzołóstwo, albo stał się jego przyczyną lub sam także popełnił cudzołóstwo ${ }^{52}$. Decyzja należy do strony niewinnej, może darować winę gdy podejmuje fizyczne współżycie z miłością małżeńską, mimo upewnienia się o zdradzie ${ }^{53}$. Domniemywa się darowanie występku, gdy strona niewinna przez czas 6 miesięcy zachowała życie wspólne ${ }^{54}$ i nie wniosła skargi do władzy kościelnej czy świeckiej. Te 6 miesięcy należy liczyć od dnia, w którym strona niewinna dowiedziała się o cudzołóstwie współmałżonka. Po upływie tego okresu na małżonku niewinnym spoczywa obowiązek przedstawienia dowodów, że nie przebaczył ${ }^{55}$. Nie wniesienie skargi jest równoznaczne ze zrzeczeniem się prawa do separacji. W przypadku gdyby małżonek sam dobrowolnie zerwał pożycie małżeńskie i zgłosił fakt do odpowiedniej instytucji kościelnej lub świeckiej wówczas ta, biorąc pod uwagę wszelkie okoliczności, rozważy, czy jest jakaś szansa na pojednanie się małżonków, przebaczenie i nieprzedłużanie separacji w czasie ${ }^{56}$.

${ }^{51}$ Zob. P. Hemperek, W. Góralski, F. Przytula, J. Bakalarz, Komentarz..., t. 3, dz. cyt., s. 336 .

${ }^{52}$ Por. P. M. Gajda, Prawo małżeńskie Kościoła katolickiego, Tarnów 2000, s. 241.

${ }^{53}$ Por. J. GoŁĄB, Instytucja separacji małżenskiej wobowiązującym Prawie Kanonicznym, Resovia Sacra 9-10 (2002-2003), s. 289.

${ }^{54}$ Por. G. Dzierżon, Separacja stała podczas trwania węzła małżeńskiego, Jus Matrimoniale 5 (2000), s. 166.

${ }^{55}$ Por. T. Rozkrut, Separacja malżeńska $w$ prawie kanonicznym oraz w prawie polskim, Polonia Sacra 6 (2000), s. 214.

${ }^{56}$ Por. P. KASPRzyK, Separacja prawna małżonków, Lublin 2003, s. 68. 
Ostatnia presumpcja dotycząca osób zawarta jest w kanonie 1707 $\$ 2$. Nie jest to typowa presumpcja prawna zwykła, ale stwierdzenie przez biskupa diecezjalnego domniemania śmierci współmałżonka. Zgodnie z normą prawną małżeństwo może być rozwiązane tylko poprzez śmierć jednego ze współmałżonków ${ }^{57}$. Jednak sprawa się komplikuje, gdy trudno stwierdzić fakt zgonu małżonka. W omawianym kodeksie nie istnieje domniemanie śmierci. Dlatego w sprawach prawno-kościelnych nie wystarczy cywilne domniemanie zgonu, ani też pogłoski o śmierci, ani racje prawdopodobne. Należy przeprowadzić taki dowód, którego wynikiem ma być pewność moralna o fakcie śmierci. Nie jest w tym wypadku konieczne, żeby takie dowodzenie wykluczyło jakieś wątpliwości, ale musi być roztropne. Ma to jednak przede wszystkim doprowadzić do pewności moralnej ${ }^{58}$. Sprawa ma się inaczej, gdy małżonek posiada dokument stwierdzający śmierć np. akt zgonu. W tym przypadku jest mowa o śmierci pewnej. Śmierć pozorna to taka, która jest na przykład przypadkowo stwierdzona przez lekarza, ale śmierć faktycznie jeszcze nie nastąpiła. Powrót do życia następuje po jakimś czasie, czy to na skutek przebudzenia ze śpiączki, albo jako wynik zabiegów reanimacyjnych. Taka śmierć nie powoduje utraty osobowości prawnej, lecz należy traktować takiego człowieka jako czasowo pozbawionego używania rozumu ${ }^{59}$. Potrzeba uznawania domniemanej śmierci jest wielka, przede wszystkim w czasie wojny, w okresach powojennych, a także w sytuacjach katastrof i zamachów terrorystycznych. Osoba która straciła współmałżonka ma problem, gdy próbuje ponownie zawrzeć małżeństwo. Stąd duszpasterze winni być gotowi na przygotowanie odpowiednich instrumentów prawnych i umieć je zastosować ${ }^{60}$.

\footnotetext{
${ }^{57}$ Por. kan. $1141 \mathrm{KPK}$.

${ }^{58}$ Por. M. Żurowski, Prawo nowego przymierza, Poznań 1989, s. 148.

${ }^{59}$ Por. M. Żurowski, Prawo nowego..., dz. cyt., s. 149.

${ }^{60}$ Por. R. Sztrchmiler, Stwierdzenie domniemanej śmierci wspótmatżonka, Jus Matrimoniale 7 (2002), s. 153.
} 


\subsection{Presumpcja dotycząca okoliczności}

W tej części zostaną poddane analizie domniemania prawne odnoszące się do zaistniałych okoliczności lub zdarzeń. Pierwszy taki przypadek znajduje się w kanonie $15 \$ 2$. Treścią tego kanonu są skutki prawne ignorancji (brak należnej wiedzy) lub błędu odnośnie do ustaw unieważniających i uniezdalniających albo regulacje dowodu ignorancji lub błędu odnośnie do ustaw i faktów. Ignorancję trzeba odróżnić od przejściowej nieuwagi oraz zapomnienia. Błąd, to natomiast fałszywy sąd o rzeczywistości. Skutki ignorancji i błędu traktuje się na równi ${ }^{61}$. Dlatego jest rzeczą obojętną, czy ktoś wie lub nie wie o istnieniu przeszkody powodującej nieważność małżeństwa. Nieznajomość niezawiniona uwalnia w tym wypadku tylko od winy subiektywnej $^{62}$. Gdy ktoś twierdzi, że działał w ignorancji lub błędzie, wówczas musi to udowodnić. Nie domniemywa się bowiem ignorancji czy błędu odnośnie do ustawy czy kary ani co do faktów własnych (np. wskutek zapomnienia), ani cudzych notorycznych (tzn. powszechnie rozgłoszonych i nie dających się utaić). Domniemywa się natomiast ignorancję lub błąd odnośnie do faktów cudzych nienotorycznych (tzn. tajnych lub znanych tylko wąskiemu kręgowi osób). W takim wypadku należy dowieść znajomość faktu. Skutki ignorancji lub błędu ocenia się wówczas według kryteriów moralnych ${ }^{63}$. Jest to domniemanie dopuszczające dowód przeciwny.

Następna presumpcja zawarta jest w kan. $57 \$ \$ 2-3$. Zawiera on normy, które są nowością w systemie prawa kanonicznego. Dotyczy m.in. odpowiedzialności administracji kościelnej za szkody spowodowane wykonaniem nielegalnego aktu administracyjnego. Kanon stanowi, że organ administracji kościelnej ma obowiązek wydać dekret administracyjny w określonym terminie. Ustawodawca w taki sposób jakoby przymusza organy kościelnej władzy wykonawczej do obowiązku wydania dekretu w przewidzianym prawem czasie. W ten sposób wyklucza się bierność organów kościelnych. Ustawodawca

\footnotetext{
${ }^{61}$ Zob. J. Krukowski (red.), Komentarz do..., t. 1, dz. cyt., s. 66.

${ }^{62}$ Por. E. Sztafrowski, Podręcznik..., t. 1, dz. cyt., s. 151.

${ }^{63}$ Por. J. Krukowski (red.), Komentarz do..., t. 1, dz. cyt., s. 67.
} 
określa termin trzech miesięcy. Natomiast upływ czasu rozpoczyna się od momentu złożenia prośby. Oczywiście są wyjątki, które mogą stanowić inny termin. Po upływie owych trzech miesięcy, gdy dekret nie został wydany, należy domniemać odpowiedź negatywną. Po upływie tego terminu wierny może wnieść kolejno dwa odwoławcze środki ${ }^{64}$. Wówczas kompetentny organ władzy wykonawczej odpowiada za milczenie administracyjne. Ustawodawca zobowiązuje go także do wydania dekretu, choćby był on negatywny, a także do naprawienia ewentualnej szkody ${ }^{65}$. Zawarta presumpcja prawna w tym kanonie jest zwykła, czyli dopuszcza dowód przeciwny.

Kolejne domniemanie traktuje o przywilejach. Jest to kan. $76 \$ 2$. Przywilej jest konkretnym aktem administracyjnym. Należy w nim wyróżnić kilka elementów. Przede wszystkim to, że przywilej jest udzielony dla pożytku określonych osób fizycznych lub prawnych. Przywileje dzieli się na dwa rodzaje: stanowione wbrew ustawie oraz obok ustawy. Kolejnym elementem jest fakt, że przywilej jest aktem partykularnym. Przywilej więc nie jest ustawą tak ze względu na swój przedmiot, jak i ze względu na adresatów. Dotyczy konkretnych osób, a nie ogółu. Następnie przywilej udziela łaski, czyli jest aktem korzystnym dla adresatów. Kompetentnym do wydawania takich aktów jest prawodawca lub posiadający władzę wykonawczą, której prawodawca dał takie uprawnienie. Przywilej można otrzymać w dwojaki sposób. Na mocy aktu kompetentnej władzy lub na mocy stuletniego lub niepamiętnego posiadania przywileju. Wówczas rodzi się presumpcja udzielenia przywileju.

Dwa kanony dalej, czyli w $78 \$ 1$ pojawia się następne domniemanie prawne zwykłe. Także dotyczy ono przywilejów. Domniema się, że przywilej jest wieczysty, czyli dożywotni. Inaczej będzie wówczas, gdy udowodni się coś przeciwnego. Prawodawca zastosował tutaj pierwotny schemat presumpcji. O dowodzie, który należy przedłożyć, aby podważyć domniemanie, mówi wprost w $\$ 1$. Wówczas taki wieczysty charakter przywileju nie oznacza że przywilej w żaden sposób nie

\footnotetext{
${ }^{64}$ Por. tamże, s. $120-121$.

${ }^{65}$ Zob. kan. 128 i $57 \$ 3$ KPK.
} 
ustaje, ale że z upływem czasu wygasa w sposób prawnie określony ${ }^{66}$. Czas trwania przywilejów zależy od różnych okoliczności ${ }^{67}$.

W Normach generalnych występuje jeszcze jedna presumpcja prawna zwykła odnośnie okoliczności, chodzi o kan. $124 \$ 2$ traktujący o czynnościach prawnych. Kanon ten określa warunki ważności czynności prawnych. Pierwszy z nich, to zdolność podejmującej ją osoby, następny występowanie wszystkich istotnych elementów konstytuujących czynność oraz wypełnienie wszystkich formalności i wymogów stawianych przez prawo do ich ważności ${ }^{68}$. Dotyczą one wszystkich czynności prawnych, zarówno urzędowych jak i prywatnych, jednostronnych i wielostronnych, forum zewnętrznego i wewnętrznego ${ }^{69}$. Gdy wszystkie elementy zostaną spełnione, wówczas zakłada się ważność czynności prawnej.

W czwartej księdze obowiązującego KPK występują kolejne presumpcje prawne zwykłe. Pierwsza z nich zawarta w kan. 1060. Dotyczy ona ważności małżeństwa. Owe domniemanie nie wybrzmiewa tutaj wprost, gdyż nie pojawia się słowo praesumptio. $\mathrm{Z}$ momentem zawarcia umowy małżeńskiej powstaje domniemanie prawne za jej ważnością. Prawodawca zaznacza, że małżeństwo cieszy się przychylnością prawa, dlatego w wątpliwości należy uważać je za ważne, do momentu udowodnienia czegoś przeciwnego. Podstawą domniemania jest fakt zawarcia małżeństwa. Presumpcja ustępuje w momencie przedłożenia dowodu przeciwnego. Stanowi ona wyraz zainteresowania społeczności kościelnej, ale też formę kontroli nad instytucją małżeństwa ${ }^{70}$. Dowód stwierdzający nieważność małżeństwa może przedstawić tylko kompetentna władza.

Następny kan. 1061 traktuje o rodzajach małżeństwa. W zależności od różnych kryteriów, jakie zostaną przyjęte, można mówić o różnych rodzajach lub postaciach małżeństwa. Małżeństwo pomiędzy

\footnotetext{
${ }^{66}$ Zob. kan. 81 i 83 KPK.

${ }^{67}$ Por. J. Krukowski (red.), Komentarz do..., t. 1, dz. cyt., s. 142.

${ }^{68}$ Por. E. Sztafrowski, Podręcznik..., t. 1, dz. cyt., s. 233.

${ }^{69}$ Por. J. Krukowski (red.), Komentarz do..., t. 1, dz. cyt., s. 203-204.

${ }^{70}$ Por. W. Gór Alski, Kościelne prawo małżeńskie, Płock 1987, s. 17.
} 
ochrzczonymi nazywa się zawarte wówczas, gdy nie zostało dopełnione. Zawarte i dopełnione wtedy, gdy małżonkowie podjęli w sposób ludzi akt małżeński, który sam z siebie jest zdolny do zrodzenia potomstwa. Aktualne prawodawstwo stwierdza, że dopełnienie małżeństwa musi być dokonane w sposób ludzki, czyli świadomie i dobrowolnie. Gwałt nie będzie podstawą do uznania dopełnienia małżeństwa. W przypadku, gdy małżonkowie ze sobą zamieszkają, wówczas domniema się dopełnienie małżeństwa ${ }^{71}$.

W kan. $1086 \$ 3$ pojawia się kolejna presumpcja. Zawarta tu norma dotyczy przeszkody rozrywającej różnej religii. Zachodzi ona między katolikiem, czyli ochrzczonym w Kościele katolickim lub do niego przyjętym poprzez formalne wyznanie wiary, a osobą nieochrzczoną. Domniemywa się, że chrzest jest udzielany ważnie. Gdyby przed ślubem byłaby wątpliwość, czy nupturient został ochrzczony albo czy chrzest był ważnie udzielony, należy przeprowadzić adekwatne dochodzenie. Gdyby podczas zawierania małżeństwa jedno z narzeczonych było powszechnie uważane za ochrzczone lub jego chrzest był wątpliwy, wówczas należy domniemywać ważność małżeństwa, dopóki w sposób pewny nie udowodni się, że jedno z nich było ochrzczone, drugie zaś nieochrzczone. Omawiany kanon ma na celu zabezpieczenie wiary strony katolickiej oraz chrzest i katolickie wychowanie dzieci zrodzonych z tego małżeństwa ${ }^{72}$.

W kan. $1101 \$ 1$ pojawia się kolejne domniemanie prawne zwykłe dotyczące małżeństwa. Kanon ten dotyczy symulacji zgody małżeńskiej. W obowiązującym prawie powszechnym bierze się pod uwagę możliwość symulacji zawierania małżeństwa przez nupturienta. Zawierający małżeństwo może jedynie tylko pozornie, czyli zewnętrznie, wyrażać zgodę małżeńską, podczas gdy w rzeczywistości ją wyklucza. Pozorna zgoda polega tylko na zewnętrznym wyrażaniu zgody, ale przy częściowym lub całkowitym sprzeciwie woli ${ }^{73}$. W omawianym kanonie wyrażona jest presumpcja, że przy zawieraniu małżeństwa

\footnotetext{
${ }^{71}$ Por. W. Góralski, Kościelne prawo..., dz. cyt., s. 17-18.

${ }^{72}$ Por. E. Sztafrowski, Podręcznik..., t. 4, dz. cyt., s. 76.

${ }^{73}$ Por. J. GręźLikowski, Czy w Kościele..., dz. cyt, s. 100-101.
} 
istnieje ścisły związek między zgodą wewnętrzną, a słowami lub znakami wyartykułowanymi na zewnątrz. Gdy ktoś twierdzi, że nie ma harmonii pomiędzy obu forami, a zgoda była jedynie pozorna, wówczas musi to udowodnić. W takiej sytuacji powyższa presumpcja upada. Sędzia, aby obalić domniemanie, powinien za pomocą niezbitych argumentów udowodnić istnienie pozytywnego aktu woli nupturienta symulującego zgodę małżeńską. Takiego aktu woli nie można domniemywać. Należy go całkowicie udowodnić na podstawie faktów i wypowiedzi, które są jasne i nie do odparcia ${ }^{74}$. Ta presumpcja nie jest jakimś przywilejem czynionym przez porządek prawny, w celu ochrony aktów dokonywanych w tym porządku, ale jest opisem jedności istniejącej w wewnętrznej strukturze zgody małżeńskiej między dwiema wolami wzajemnego zawarcia małżeństwa a ich zewnętrznym wyrazem ${ }^{75}$.

W KPK domniemywa się, że raz wyrażona i wcześniej nie odwołana zgoda małżeńska, mimo nieważności zawartego związku, z powodu przeszkody lub braku formy, trwa aż do uzyskania pewności o jej odwołaniu. Takie założenie o zgodzie małżeńskiej zawarte jest kan. 1107. Zgoda małżeńska jako przyczyna sprawcza umowy małżeńskiej, stanowi istotny moment w strukturze wewnętrznej samego małżeństwa. Raz wyrażona trwa aż do odwołania, jeśli małżeństwo zostało zawarte nieważnie. Jednak nawet nieważne zawarcie umowy małżeńskiej nie przesądza o odwołaniu konsensu. Dlatego prawodawca stanowi, iż chociaż małżeństwo zostało zawarte nieważnie $\mathrm{z}$ racji przeszkody lub braku formy, to jednak domniemywa się, że wyrażona zgoda trwa, dopóki nie uzyska się pewności jej odwołania ${ }^{76}$. Owe domniemanie podyktowane jest przede wszystkim troską Kościoła o uważnienie małżeństwa. Omawiana presumpcja dopuszcza

\footnotetext{
${ }^{74}$ Por. J. Krajczyński, Positivus actus voluntatis jako istotny element $w$ dowodzeniu nieważności małżeństwa $z$ tytułu wykluczenia nierozerwalności, Jus Matrimoniale 4 (1999), s. 84-85.

${ }^{75}$ Zob. G. LeszCZYŃski, Exclusio boni fidei jako symulacja zgody małżeńskiej (kan. 1101 § 2), Łódź 2004, s. 53.

${ }^{76}$ Zob. W. Góralski, Kościelne prawo..., dz. cyt., s. 75.
} 
dowód przeciwny poprzez wykazanie, iż w danym wypadku nastąpiło odwołanie zgody przez narzeczonych lub jedno $z$ nich.

Dalsze domniemania prawne zwykłe dotyczące okoliczności występują w kan. 1137 i $1138 \$ 2$. Traktują one o skutkach małżeństwa. Według istotnej zasady, za dzieci prawego pochodzenia uważa się poczęte lub urodzone w małżeństwie ważnym lub domniemanym. Dzieci urodzone z małżeństwa domniemanego, czyli uchodzącego za ważne, chociaż obiektywnie z przyczyn ukrytych takim ono nie jest, są prawego pochodzenia. Pierwszy z obu kanonów nie ma użytego wprost słowa „domniemanie”. Ponieważ ustalenie ojcostwa wcale nie musi być taką prostą sprawą, dlatego prawodawca podaje kan. $1138 \$ 1$, w którym za ojca uważa się tego, na kogo wskazuje prawny związek małżeński. Można to założenie prawne obalić przy pomocy niezbitych argumentów przeciwko ojcostwu. Domniemanie to ma na uwadze przede wszystkim dobro dziecka, gwarantując mu ślubne pochodzenie. Dla obalenia tego domniemania nie wystarczy tylko zwykłe oświadczenie małżonka, że nie jest ojcem dziecka zrodzonego przez żonę. Wystarczający argument to taki, który wykaże fakt nieobecności męża podczas poczęcia się dziecka ${ }^{77}$. W związku z tym należy mieć na uwadze terminy, o których traktuje kan. $1138 \$ 2$. Presumpcja tutaj zawarta traktuje o ślubnych dzieciach, które się urodziły przynajmniej po 180 dniach od zawarcia małżeństwa lub w ciągu 300 dni od przerwania pożycia małżeńskiego. Każde dziecko urodzone w tym okresie będzie uważane za pochodzące $\mathrm{z}$ prawego małżeństwa, nawet gdyby rzeczywistość była inna. Aby tak było, musi być spełniony jeden bardzo ważny warunek: ten fakt nie może być publicznie znany. Gdyby ten warunek był nie spełniony, wówczas domniemanie musi ustąpić prawdzie.

Presumpcja prawna, związana $\mathrm{z}$ małżeństwem, występuje jeszcze w kan. 1150. Podobnie jak w kan. 1137 domniemanie nie wybrzmiewa tutaj wprost. W przypadku wątpliwości, przywilej wiary cieszy się przychylnością prawa. Mogą istnieć różne sytuacje wątpliwe. Przykładem może być wątpliwość czy małżeństwo osób nieochrzczonych

\footnotetext{
${ }^{77}$ Por. E. Sztafrowski, Podręcznik..., t. 4, dz. cyt., s. 157-158.
} 
było ważnie zawarte. $\mathrm{W}$ takich sprawach spornych rozwiązaniem jest presumpcja, która stawia na pierwszym miejscu dobro duchowe wiernych. Koniecznie muszą to być wątpliwości rozumne, których nie da się usunąć, np. brak pewności czy małżeństwo pogan zostało ważnie zawarte, albo która $\mathrm{z}$ wcześniejszych żon jest prawdziwa.

Ostatnim domniemaniem w części dot. okoliczności będzie występujące w kan. $1321 \$ 3$. Kanon ten traktuje o domniemaniu poczytalności. Źródłem poczytalności jest wina umyślna lub nieumyślna. Presumpcja zawarta w omawianym kodeksie została poszerzona o winę nieumyślną. Warto zaznaczyć, że w myśl założeń reformy prawa karnego przejawem jego złagodzenia miało być m.in. zrezygnowanie z presumpcji winy umyślnej i wprowadzenie w to miejsce domniemania poczytalności. Gdy przyjmiemy, że owa presumpcja nie wskazuje na winę umyślną, wówczas już całkowicie byłoby niezrozumiałe, gdyby wskazywało na winę nieumyślną. Domniemanie zawarte $\mathrm{w} \$ 3$ oparte jest na przesłance, że człowiek jest odpowiedzialny za swoje czyny, bo podejmuje je świadomie i dobrowolnie ${ }^{78}$. Poczytalność przestępcy, jako element wewnętrzny, nie jest łatwa do ustalenia dla wymiaru kary. Istnieje presumpcja prawna poczytalności, czyli wewnętrznej winy, jeżeli zaistniało zewnętrzne naruszenie normy karnej. Ma to bardzo wielkie znaczenie praktyczne. Gdy ktoś popełnił zewnętrzne naruszenie, wówczas uważany jest za winowajcę, którego należy ukarać. Natomiast gdy jest niewinny z powodu braku poczytalności, to wtedy należy tą winę mu wykazać. Należy użyć takich argumentów, które by obaliło domniemanie prawne. W praktyce nie można się posługiwać tym domniemaniem w sposób mechaniczny. Ordynariusz lub sędzia powinien przed wymierzeniem kary zbadać, czy istnieją okoliczności zmniejszające lub wyłączające poczytalność oraz okoliczności zwiększające poczytalność ${ }^{79}$. Ma to także swoje zastosowanie przy karach latae sententiae. Z tym jednak, że w tym wypadku albo sam sprawca działania urabia sobie

\footnotetext{
${ }^{78}$ Por. J. Sy ry JCZy K, Sankcje w Kościele, Warszawa 2008, s. 122-123.

${ }^{79}$ Por. W. WójCik, J. KRukowski, F. Lempa, Komentarz do kodeksu prawa kanonicznego, t. 4, Lublin 1987, s. 191.
} 
sumienie niewinności, a zatem i niekaralności, albo też przedstawia rzecz spowiednikowi, który mu przeprowadza tego rodzaju ocenę. Ta presumpcja dopuszcza wyjątek. Chodzi o tych, którzy stale są pozbawieni używania rozumu. Mogą to być umysłowo chorzy lub psychicznie niedorozwinięci. Omawiany kodeks uwalnia takie osoby od winy oraz od karalności, mimo iż w chwili naruszenia normy sprawiali wrażenie ludzi psychicznie normalnych i zdrowych umysłowo. W niektórych przypadkach mogą się tu rozminąć, w jakimś poszczególnym wypadku, wina z karą. Spowodowane to jest chwilowym przebłyskiem świadomości i poczytalności w chwili naruszania prawa. Dla uniknięcia jednak takich przypadków, prawodawca całkowicie zwalnia ich z odpowiedzialności karnej. Pozostawia ich w kręgu odpowiedzialności moralnej ${ }^{80}$.

\subsection{Presumpcja dotycząca rzeczy}

Pierwsze domniemanie prawne zwykłe dotyczące rzeczy znajduje się w kan. $510 \$ 4$. Kanon ten określa relacje między kapitułą katedralną, a parafią katedralną. Zakaz łączenia kapituły katedralnej i parafii katedralnej został określony w $\$ 1$ rzeczonego kanonu. Jest to konsekwencja reguły z kan. 520, iż osoba prawna nie może zostać proboszczem. W tym kanonie prawodawcy bardzo zależy, aby odłączyć kapitułę katedralną od parafii. W związku z tym zaleca biskupowi diecezjalnemu, aby odłączyć ją od parafii. Konsekwencją tego rozdziału są dalsze przepisy regulujące stosunki między tymi dwiema instytucjami m.in. obowiązki i uprawnienia proboszcza i kapituły kanoników, tak aby zapobiec wszelkim konfliktom między nimi. W razie konfliktów biskup ma obowiązek rozstrzygać je osobiście, mając na uwadze przede wszystkim dobro wiernych. W przedmiotowym kanonie przyjmuje się presumpcję na rzecz parafii. Bowiem gdyby się pojawiła wątpliwość co do tego, czy ofiary składane są na kościół, który jest jednocześnie kapitulny i parafialny, wówczas należy je skierować z przeznaczeniem na cele parafialne. Domniemanie to

\footnotetext{
${ }^{80}$ Por. J. Dudziak, Kościelne prawo karne nowego kodeksu, Kielecki Przegląd Diecezjalny 5 (1983), s. 202-203.
} 
może zostać obalone, gdy zostanie dowiedzione, że ofiarodawca złożył ofiarę na cele kapituły ${ }^{81}$.

Następna presumpcja dotycząca rzeczy zawarta jest w kan. 950. Dotyczy ona ofiar mszalnych. Jeżeli ktoś złożył pewną sumę pieniędzy na odprawienie Mszy świętej, ale nie określił ich liczby, wówczas należy tę liczbę ustalić według wysokości ofiary mszalnej określonej lub przyjętej zwyczajowo w miejscu zamieszkania ofiarodawcy. Wtedy należy odprawić tyle Mszy św. w jego intencjach ${ }^{82}$. Presumpcja o przeciwnej intencji ofiarodawcy musi być oparta na uznanych prawem przesłankach. Aby wykluczyć niepotrzebne wątpliwości, najlepszym sposobem na rozwiązanie sporu jest zapytanie się ofiarodawcy, jaka jest jego wola ${ }^{83}$.

Ostatnie z domniemań zawarte jest w kan. $1267 \$ 1$ dotyczy kwestii nabywania dóbr. O ile nie wiadomo czegoś innego, domniemywa się, że ofiary składane przełożonym lub administratorom jakiejkolwiek kościelnej osoby prawnej, również prywatnej, zostały złożone na własność tejże osoby prawnej. Sprawa dotyczy rzeczy wręczonej bezpośrednio, a nie świadczeń. Norma ta ma zastosowanie wtedy, gdy nie ma konkretnego celu darowizny. W normalnych wypadkach darowizna ruchomości powinna być dokonana na piśmie, natomiast darowizna nieruchomości poświadczona aktem notarialnym. Presumpcja o przeznaczeniu ofiary na rzecz osoby prawnej dotyczy ofiar składanych na ręce wszystkich przełożonych i zarządców kościelnych osób prawnych. Domniemanie to powinno ustąpić przed słuszną świadomością, że ofiara złożona ma charakter indywidualny, czyli jest przeznaczona dla danej osoby fizycznej, np. dla proboszcza. Wówczas nie są potrzebne dowody przeciwne ${ }^{84}$.

\footnotetext{
${ }^{81}$ Por. J. Dyduch, W. Góralski, E. Górecki, J. Krukowski, M. Sitarz, Komentarz do kodeksu prawa kanonicznego, t. 2/1, Poznań 2005, s. 403; E. SzTAFrowski, Podręcznik prawa kanonicznego, t. 2, Warszawa 1985, s. 186.

${ }^{82}$ Por. P. Hemperek, W. Góralski, F. PrzytuŁa, J. Bakalarz, Komentarz do..., t. 3, dz. cyt., s. 144.

${ }^{83}$ Por. E. Sztafrowski, Podręcznik..., t. 3, dz. cyt., s. 229.

${ }^{84}$ Zob. T. Pawluk, Prawo kanoniczne..., t. 4, dz. cyt., s. 35.
} 


\section{Zakończenie}

Celem niniejszego opracowania było prześledzenie konstrukcji zastosowanych w przypadkach użycia presumpcji prawnych w Kodeksie Jana Pawła II z 1983 r. Na podstawie zastosowanej analizy można stwierdzić, że w prawie kościelnym występują tylko domniemania prawne. Domniemania faktyczne, czyli sędziowskie, może wnioskować sędzia na podstawie toku rozumowania. Do tego domniemania nie jest potrzebne uregulowanie prawne, ponieważ wynika z samego logicznego rozrachunku. Trzy grupy domniemań prawnych wskazują na ilościowy wymiar jak i jakościowy zakres presumpcji $\mathrm{w}$ prawie kanonicznym. Jak z zaprezentowanego zestawienia wynika najwięcej presumpcji prawnych zawartych w kodeksie obowiązującym w Kościele łacińskim dotyczy okoliczności, jest ich aż 13, o dwie pozycje mniej znajdziemy w grupie presumpcji dotyczących osób, zaś zaledwie trzy domniemania dotyczą rzeczy. Spośród 27 zastosowanych w kodeksie presumpcji większość (14) uplasowała się w księdze czwartej regulującej uświęcające zadania Kościoła, siedem z presumpcji dotyczy norm ogólnych (I księga), zaś pozostałe po jednym domniemaniu znajdziemy w księgach: III, V, VI i VII, pozostałe dwa przeanalizowane przypadki zawierają się w księdze II. Najczęściej domniemania w prawie kanonicznym występują w kanonach traktujących o małżeństwie. Warto jeszcze wspomnieć, że nie we wszystkich przypadkach mamy do czynienia z łac. paesumptio lub z tłumaczonym na język polski domniemanie. Pojawiają się bowiem sformułowania analogiczne lub znaczeniowo bardzo bliskie np. domyślnie, oddające w kontekście swego uplasowania znaczenie o które chodziło w niniejszym przedłożeniu.

\section{Praesumptio at John Paul II Code of Canon Law of 1983}

There is variety of synonyms being used in Polish language to describe Latin praesumptio.

At law sciences presumption is an interdisciplinary phrase and so it is not unambiguous. Therefore it is worth monitoring the types of the 
presumptions and the context of their appearance at John Paul II Code of Canon Law (CCL) of 1983.

In general, we divide the presumptions into actual or judicial ones and those of law - assumed by the legislator. The former ones are drawn from authentic prerequisites. It creates the possibility to reach an objective truth. The more consistent conclusions that the judge will draw from different prerequisites the greater possibility will be reached. The latter ones - the presumptions of law - rely on assuming some facts, based on legal provisions, as proven, in case of lack of the contrary evidence. They're divided into ordinary (relative) and absolute ones. The ordinary presumption can be refuted if false conclusions are proven. An absolute presumption takes place if the legislator refuses to admit directly the contrary evidence and assumes indirect one.

The Author of the Code applies the ordinary presumptions of law only (mutable ones) which means that they can be refuted by counter-evidence. As regards the actual presumptions - they do not occur at CCL-83. They're assumed by the judge during the trial.

The John Paul II CCL applies the presumption of law with respect to the persons, circumstances and objects. Based on thorough analysis of the code contents it results that the most of the presumptions relates to the circumstances (there are as much as 13); we'll find two less as regards the persons and only three regarding the objects. Of all 27 presumptions applied in CCL - we'll find 14 in Book IV regulating the office of sanctifying in the Church, 7 applies to general norms (Book I) and the remaining ones we'll find in Books: III, V, VI and VII; the last 2 contains Book II. Most of the presumptions in CCL occur in canons referring to the marriage.

SŁOWA KLUCZOWE: domniemanie faktyczne; domniemanie prawne; domniemanie zwykłe wzruszalne

KEY WORDS: actual presumption; presumption of law; ordinary mutable presumption

\section{Nota o Autorze:}

Ks. DR hab. KaZimierz Dullak, Prof. US - Dziekan Wydziału Teologicznego Uniwersytetu Szczecińskiego, kierownik Katedry Prawa Kanonicznego. 